\title{
Doodia hindii ( Blechnaceae) a new species from north eastern New South Wales, Australia
}

\author{
T. Carrick Chambers
}

\author{
National Herbarium of NSW, Mrs Macquaries Road, Sydney, NSW 2000, Australia \\ Email: carrick.chambers@rbgsyd.nsw.gov.au
}

\begin{abstract}
Doodia hindii Tindale ex T.C.Chambers is described for the first time. This is a rarely collected species from rainforest in mountain regions of north eastern New South Wales, bringing to nine the number of species of Doodia in Australia .
\end{abstract}

\section{Introduction}

The genus Doodia (Blechnaceae) is estimated to contain more than 30 species distributed through Australasia, Papuasia, Malesia, Sri Lanka and the Pacific region extending north east to Hawaii and as far east as Easter Island (Parris 1972, 1998). Hybrids have been reported among some of the species especially in the D. caudata complex (Andrews 1990). Eight species have been defined by Parris (1998) in the Flora of Australia treatment. By modifying the key provided there, this additional (ninth) Australian taxon can be accommodated as follows (modifications are in italics):

4: Numerous strongly reduced basal pinnae/segments present; abaxial surface of pinnae/segments mid vein either with or without tubercles

5 Rhizome erect, forming caudex up to $30 \mathrm{~cm}$

1. D. maxima

5: Rhizome short to long creeping; tubercles present on stipe

5. D. australis

5a Rhizome short (but may develop an erect caudex); stipe glabrous, dark at the base, usually stramineous at least on the adaxial surface, smooth, shiny, and without tubercles

9. D. hindii

\section{Taxonomy}

Doodia hindii Tindale ex T.C.Chambers sp. nov.,

Fig. 1 a-d

Rhizoma caespitosum vel breve repens; caudex $1.5 \mathrm{~cm}$ diametro usque ad $16 \mathrm{~cm}$ elatus; frons $40(-50) \mathrm{cm}$ longa aut pendens aut patens frondibus maturis plerumque fertilibus; stipes laevigatus glaber, adaxialiter aureus vel stramineus, abaxialiter purpureus apicem versus rhachidis gradatim lutescens. 


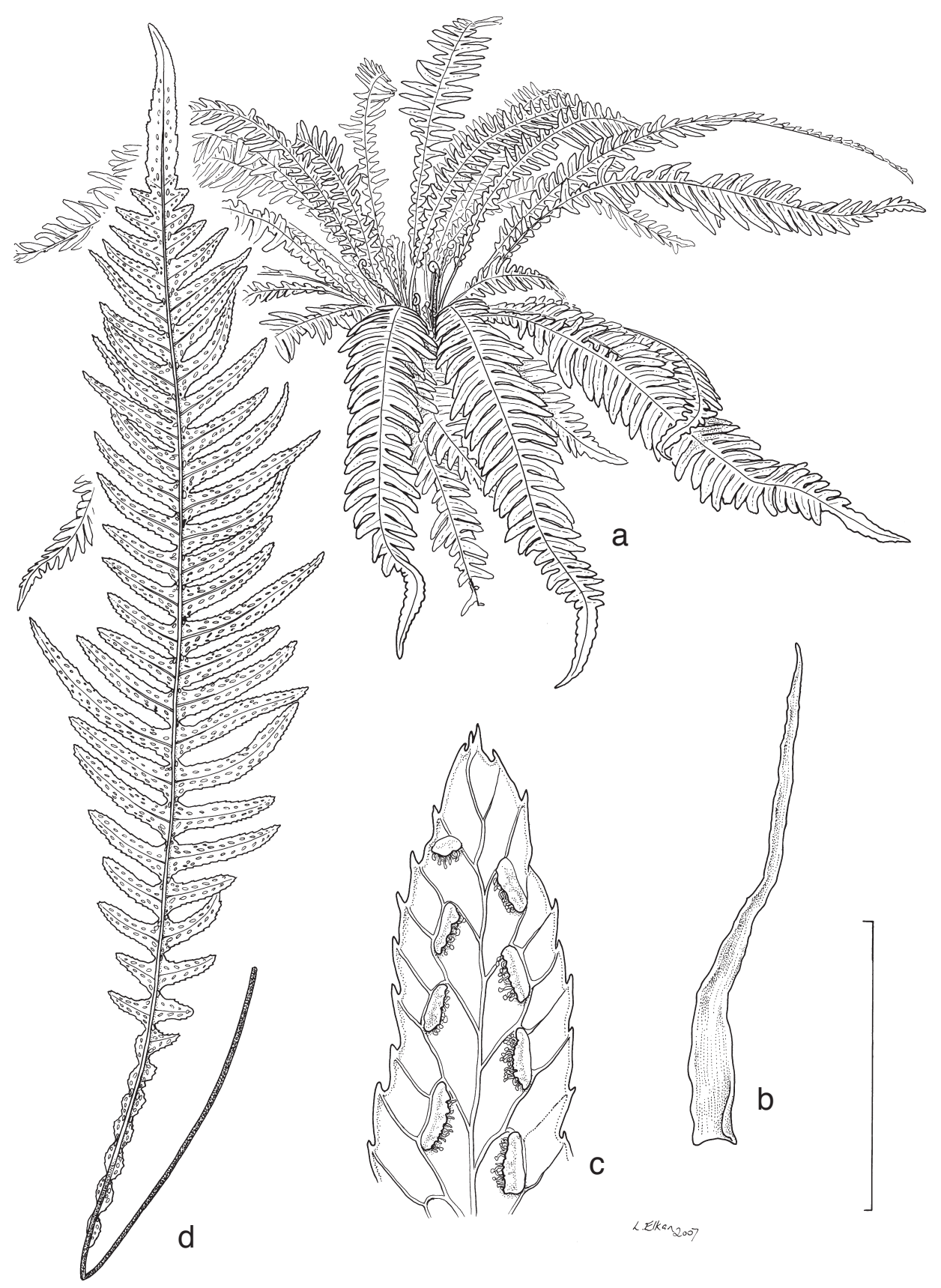

Fig 1. Doodia hindii. a, habit of plant growing in soil in a flat area. b, typical scale from the base of the stipe. c, abaxial surface of the apical half of a segment showing detail of venation, and sporangia. d, abaxial surface of mature frond (a,b from living collections at the Fernery at RBG Sydney c, d from Coveny $10555 \&$ Hind). Scale bar: $\mathrm{a}=15 \mathrm{~cm} ; \mathrm{b}=2.5 \mathrm{~mm} ; \mathrm{c}=7.5 \mathrm{~mm}$; $\mathrm{d}=7.5 \mathrm{~cm}$. 
Type: New South Wales: North Coast: Eden Creek Falls, Toonumbar State Forest, $20 \mathrm{~km}$ NW of Kyogle, near the Queensland border, locally common on steep slopes in rain forest near falls with Pellaea nana, Lastreopsis munita, Adiantum spp. $28^{\circ} 30^{\prime} \mathrm{S}$ $152^{\circ} 48^{\prime} \mathrm{E}, \mathrm{R}$. Coveny 10555 \& P. Hind, 25.12.1979; holotype: NSW 507718; isotypes: MEL, CANB, ABRI, \& AK.

Rhizome short creeping, tufted erect to sub-erect, caudex 1.0-1.5 cm diameter; and up to $15 \mathrm{~cm}$ in height in older plants (in cultivation) supporting a crown of arching or pendulous fronds $20-40(-50) \mathrm{cm}$ long, often pendulous (in specimens growing on steep banks) but distinctly flat and spreading for plants established on level soil areas; stipes smooth (no tubercles), deeply grooved on the adaxial surface, 9-15 (-20) cm long with basal scales persistent, lustrous black to matte dark red-brown, long-acuminate, essentially entire, (sometimes with an occasional minute marginal outgrowth); stipes black at the base becoming paler and stramineous in most specimens towards the rhachis, usually much shorter than the lamina and with a deep groove adaxially; rhachis with a conspicuous deep single groove on the adaxial face extending for its full length; and adaxially the rhachis on most specimens pale stramineous and shiny; in larger plants the dark pigmentation of the stipe extending up the smooth, abaxial surface grading to stramineous towards the apex; lamina rich olive to dark green adaxially, linear-lanceolate, pinnate and with a variable number of usually contiguous reduced photosynthetic adnate segments (auricles) towards the lamina base; in some plants there is a single larger pair of sessile very shortly stalked pinnae; all segments including the auricles (and pinnae at the lamina base if present) usually fertile; auricles with 1-3 sori, the fully developed segments with 5-15 sori per single row each side of the costa, each sorus attached to a commissural vein on the side facing the costa; indusium single thin, papery, pale-brown to fawn-coloured, entire, arising on the side of the vein nearest to the segment margin; segments lanceolate in outline, 3-5 mm wide $1-3(-5) \mathrm{cm}$ long, the apices varying from acuminate to somewhat attenuate with margins distinctly dentate; venation typical for the genus, more conspicuous on the paler abaxial surface, and with each commissural vein supporting a sorus and usually with two vein branches each terminating at a separate marginal tooth arising from the slightly thickened segment margin; terminal segment longer than the lateral segments, $4-6 \mathrm{~cm}$ long and up to 8 $\mathrm{mm}$ wide at its base, caudate, acuminate, and usually fertile.

Spores: 64 per sporangium, (this count was made by P. Kodela for Dr M. Tindale).

Chromosomes: under Doodia sp Wiangaree SF, NSW, P. Hind 2750 (NSW) and Wiangaree P.D, Hind 2568, Tindale and Roy (2002) report $2 \mathrm{n}=64$ (diploid); see their fig.142, photomicrograph illustrating $\mathrm{n}=32$ bivalents.

Distribution and habitat: known only from four sites in open forest and rainforest in mountainous areas in north eastern New South Wales one close to the border of Queensland. Collectors have noted that there were other species of ferns also present including Macrothelypteris torresiana, Doodia media $[=$ D. australis], D. aspera, D. caudata and D. linearis. Specimens of Doodia hindii are also reported from earth banks above a stream, on steep slopes under rainforest and from open areas near waterfalls (in this latter locality associated with Pellaea nana, Lastreopsis munita and Adiantum spp.).

Specimens studied: New South Wales: North Coast: Logan Creek, Mount Kripps, Wiangaree State Forest, (Lions Road) near waterfall on earthy banks of stream, locally common, $28^{\circ} 21^{\prime} \mathrm{S}$, 152 $2^{\circ} 7^{\prime} \mathrm{E}$, Hind 2570 \& Coveny, Dec 1979 (NSW428416, AK, BRI, K); Palm Gully a tributary of 
Long Creek on steep earth banks, NE of Wiangaree in Wiangaree State Forest, $28^{\circ} 23^{\prime} \mathrm{S} 152^{\circ} 55^{\prime} \mathrm{E}$, Hind 2568 \& Coveny, living collection No 800022 RBG Sydney, (NSW428578); Eden Creek Falls $20 \mathrm{~km} \mathrm{NW}$ of Kyogle, Toonumbar State Forest, $28^{\circ} 23^{\prime} \mathrm{S} 152^{\circ} 48^{\prime} \mathrm{E}$, locally common on steep slopes in rain forest near falls with Pellaea falcata var. nana, Lastreopsis munita, Adiantum spp., Coveny 10555 \& Hind, Dec 1979 (NSW507718, BRI, BM, CBG, E, K, US); Mt Warning National Park, 9 miles (14.5 km) SW of Murwillumbah, on cliff faces with Bulbine, Cyperus, Plectranthus, Nephrolepis, etc., 2824'S 153²16'E, Coveny 4528 \& Rodd, Sep 1972 (NSW245336).

Conservation Status: currently Doodia hindii is only recorded from a very limited part of far north-eastern NSW in relatively inaccessible, rugged forested, mountainous areas. Unless further discoveries are made in the adjoining southern Queensland national parks or other conserved areas, $D$. hindii must be regarded as a vulnerable species. Threats to this species would be from uncontrolled bushfires and clearance for road construction and/or forestry activities.

Notes: 1. Doodia australis (Parris) Parris is possibly the species most closely related to D. media and was originally described from New Zealand material as a sub-species of D. media. In the Flora of Australia 48: 710 (1998), Parris made the decision to separate $D$. australis from D. media and its associated D. caudata complex and in doing so recognised D. australis as a much more widespread taxon from Australia, in eastern Qld south of latitude c. $25^{\circ}$ and in eastern N.S.W. Vic. and Tasmania as well as New Zealand, Lord Howe Is.and Norfolk Is.

2. One immature collection of Doodia from McPherson Range in south eastern Queensland may possibly belong to D. hindii (NSW507717). However basal relatively long segments and very fine stipes suggest either a hybrid origin or if further specimens over a wider geographic area are discovered possibly a separate taxon.

3. Almost certainly additional collecting in north-eastern New South Wales and southeastern Queensland will lead to extending our knowledge of Doodia hindii and of other taxa in this genus.

\section{Acknowledgments}

Dr Mary Tindale, some years ago recognised that the above collections represented a distinct and probably undescribed taxon giving these the provisional specific name 'hindii' and she has agreed to my preparing a description for publication. We thank Mr Peter Hind and Mr Bob Coveny, Technical Officers, National Herbarium of NSW, for their careful collections and observations and their helpful comments, Lesley Elkin for the skilled drawings to illustrate the morphology of $D$. hindii, Dr Peter Wilson for advice on the Latin diagnosis and general advice on the manuscript, Dr Philip Kodela who had provided the spore count on herbarium material when Dr Tindale was first investigating this species and Dr Tim Entwisle Executive Director (Gardens Trust) for providing facilities for this study. 


\section{References}

Andrews SB (1990) Ferns of Queensland: 97. (Queensland Dept Primary Industries: Brisbane) Parris BS (1972) The genus Doodia R.Br. (Blechnaceae: Filicales) in New Zealand. New Zealand Journal of Botany 10: 585-604.

Parris BS (1998) Doodia. Pp. 390, 710, fig 131 D-E in McCarthy PM (ed.) Flora of Australia, vol. 48. (ABRS/CSIRO: Australia)

Tindale MD \& Roy SK (2002) A cytotaxonomic survey of the Pteridophyta of Australia. Australian Systematic Botany 15: 839-937.

Manuscript received 15 January 2008, accepted 01 April 2008 